\title{
The physical capacity of different professional groups of Brazilian Amazonians, studied by cycle ergometry(*)
}

Vichi, F. L. "*

Souza, J. M. *t*

\begin{abstract}
A study of the physical performance of seven different professional groups living in the Brazilian Amazon was performed. The level of the physical capacity was measured using the ergometric bicycle. The professional groups (10 persons each) were the following: military groups, rural workers, river workers from the fluvial harbor of the city of Belém, primitive Kayapó indians. The other groups were professional soccer players, sedentary working persons and urban workers -5 people of each. The best physical capacity was obtained by the soccer players and military groups. In second place, having small differences were the remaining groups, except the sedentaries. These persons revealed very low physical performance. As a general generalization the amazonians, although living in an environment of very high temperatures and humidity, are in about the same physical condition as those living in the interior of State of São Paulo (city of Ribeirão Preto). The amazonian rural workers reached better physical condition when compared to those studied in the State of São Paulo. Our preliminary explanation for such a result is the ingestion of a more balanced diet by the amazonians who have mainly high protein intake. The primitive Kayapó indians, perhaps studied for the first time, showed a physical performance comparable with the average of the other workers.
\end{abstract}

\section{INTRODUCTION}

The determination of physical performance of normal persons has gained a great deal of importance in the past few years (Astrand, 1952; Balke et al. 1954; Balke \& Ware, 1959; Fundamentals of Exercise Test 1971; Gardner et al., 1977). In spite of the volume of studies ranging from basic physiology to the practical applications of these measurements, the knowledge of the human physical capacity has very many actual implications (Fundamentals of Exercise Testing, 1971) .

In a prior work we displayed our experience analyzing distinct professional groups living in the southern part of Brazil (Gardner et al., 1977; Vichi et al. 1976). After this initial apprcach to the subject, we charged our interest to the area of the Brazilian Amazon. The reasons for this choice were the various aspects of life and adaptation which differ widely between these two populations. Among these differences we should point out as the most important: ethnic composition, mesological situation, food ingestion, habits, nutritional status and type of work.

This paper is a first attempt to determine the physical performance of several different normal groups of people living and laboring in the tropical Brazilian Amazon. A relevant fact we have to indicate, is that among the Amazonians we were able to study, were ten primitive kayapó indians. This observation is probably unique and original because of the fact of the rapid and irreversible civilization habits that the ndians are assuming.

As basic equipment to measure this biological function we used the ergometric bicycle. Although other methods are described, we prefered this technique because of our own experience and the feasibility of the test.

Our purpose in doing this work was first of all to find out the physical performance of groups of Amazonians, and secondarily it was to obtain some comparison between these results and those already described for men living in the southern part of Brazil.

(*) Work done in the city of Belém (July-August - 1976) under the sponsorship of the Instituto Nacional de Pesquisas da Amazônia.

(*) - Department of Internal Medicine - Ribeirão Preto Medical School - University of São Paulo - 14100 - Ribeiräo Preto - Brazil.

(**) - University of Pará - Presently Director of the Instituto Médico-Legal Renato Chaves - 66000 - Belém - Brazil. 


\section{MATERIAL AND METHODS}

All work was done in the city of Belém, located at the mouth of the Amazon river. Seven different populational groups were selected for the study: river workers, soldiers, Kayapó indians, (10 men of each), professional soccer players, sedentary workers and urban workers (5 men of each).

Prior to the test, all persons had a questionaire to be filled out regarding socio-economic situation, food ingestion, physical activities and past medical history. Also complete physical examinations and conventional electrocardiograms were done. The traces, although normal, were kept as documentation. Some serum biochemical examis were done (hematocrit, glucose, BUN proteins) to complete the medical routine.

The soldiers had been recently enlisted in the army with less then two months of training. The indians were living in the jungle, walking almost the entire day, picking up Brazil nuts which were scattered in the forest. After getting a sufficient amount of nuts, they carried the fruits to a civilized advanced government post, in order to exchange them for foods, mainly salt. Ten of the healthier indians were invited to visit the city to participate in this and other medical and physiological projects. In Belem they stayed in the "Indian House", a place very similar to their natural habitat. Apparently the change of environment did not cause stress for the indians.

They had prior contact with the Laboratories and had been trained before the exam. Two translators taught them the procedures, and all indians seemed to enjoy the experiment. They did not have great difficulties using the bicycle. A rubber strap was attached to the right foot and rolled around the pedal. The other side was handled by one of us (figure 1). With this device, it was practically impossible for them to move the cycle in a retrograde Way.

The other groups were formed by people doing normal local work. The river workers were persons who unloaded ships almost every day. The sôccer players were professional

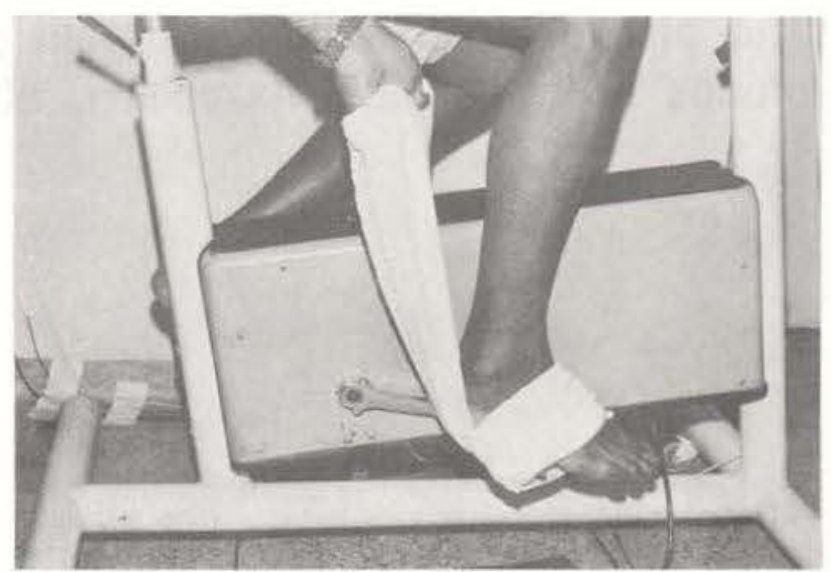

Figure 1 - Device used in order to avoid the retrograde movement of the pedal of the ergometric bicycle.

athletes in a period of heavy training. The rural workers who lived in the interior, about 60 kilometers from Belem were doing their duties which consisted of planting aromatic trees. The urban workers were constructing houses. The sedentary workers were medical doctors who engaged very little physical activity.

The technique to determine their physical performance was the same as previously presented (Vichi, 1976). The tested person bicycled against increased loads during certain periods of time followed by intervals of rest. Figure 2 illustrates hte type of exam used for exercise and rest. The procedure ended when the subject reached a cardiac frequency of 195 beats per minute (Fundamentals of exercise testing, 1971). The phase of the exam in which the above rate was obtained, was used to define degrees of physical performance. The temperature in the laboratory varied from 22 to $25 .^{\circ} \mathrm{C}$. during the test. (').

\section{Discussion}

The results found in this investigation brought up some expected conclusions. They have shown a certain relationship between the degrees of physical performance obtained and the work routinely done by the professional. The best physical capacity that was revealed

(1) - This method of tẹting is used in the Hospital das Clínicas de Ribeirăo Preto - University of Sảo Paulo, Brazil. 
by the group of athletes and the worst which was demonstrated by the sedentaries are normally expected.

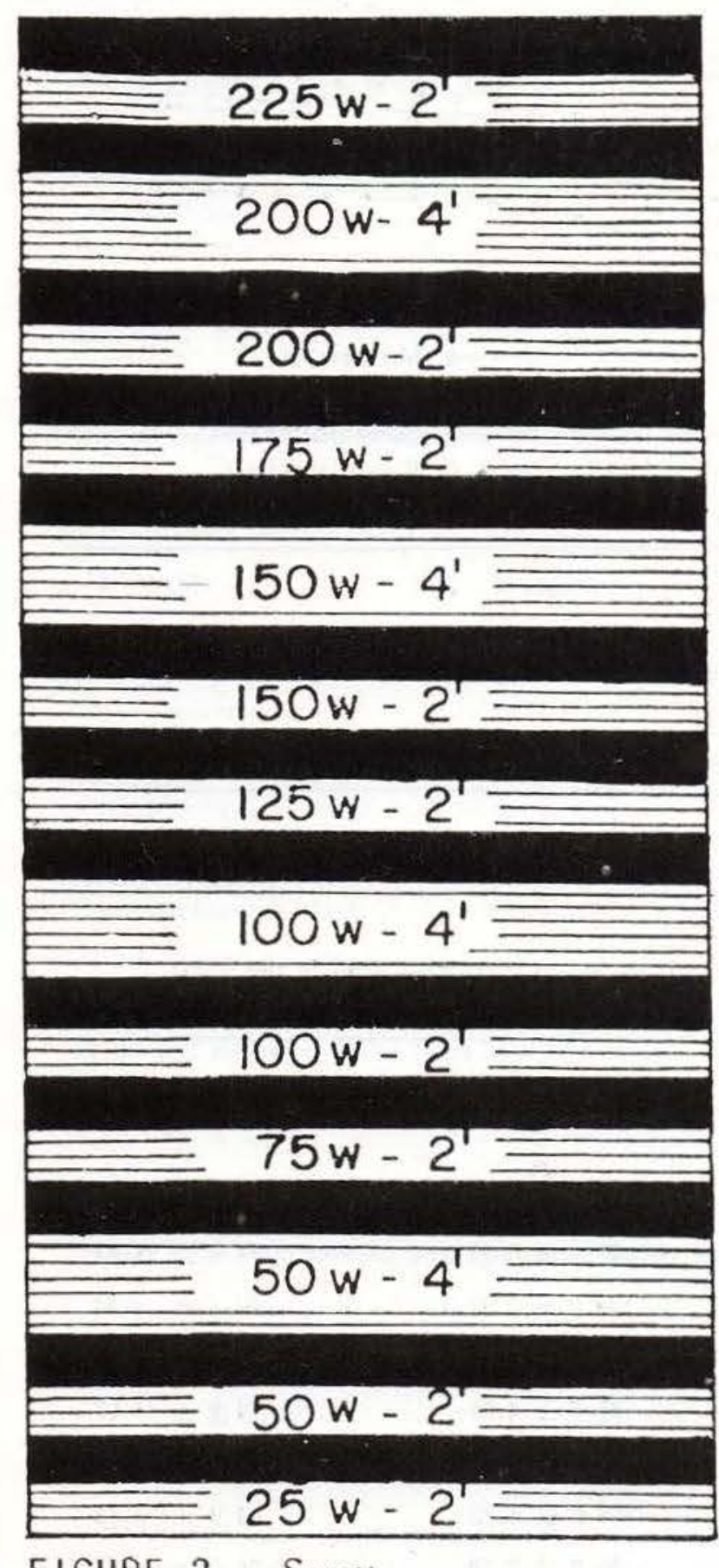

FIGURE 2 - SWqu

Figure 2 - Sequence of the test of physical performance. From the bottom to the top the increase of loads in watts $(w)$ with respective time for exercise. The black stiips mean 2 minute of rest.
Also the groups with intermediary positions have shown expected. In opposition to our first study regarding this subject, the relatively poor performance of the rural workers was not observed. As a matter of subsequent discussion, we will try to explain the possible reason why the rural workers of the Amazon had better capacity than those working in the State of São Paulo.

A very important and intersting observation was related to the physical performance demonstrated by Kayapó indians. In spite of the limitation of the test method that may have caused some additional stress to the indians (event not really suggested), they reached very satisfactory. They had a better classification than the rural workesr, who labor every day in a programmed way.

During the evolution of the test, the indians demonstrated an easy control of the method. A fact that was almost universal among the Kayapós and should be noted as a curiosity was the very small amount absence of perspiration during the exercise. Although we could note make a documentation of this, the other professionals who ended the test exhibited a great amount off sweat. There are no explanations for these findings.

The revision of the protocols have demonstrated, under the nutritional point of view, an acceptable balanced diet with a high protein ingestion among all studied persons. In the same way, a high vitamin intake is supposed to occur due to the great fruit comsumption.

This degree of protein ingestion is uncommon in Brazil. The Amazon region may be one exception due to the great number of rivers with many species of edible fishes. This nutritional peculiarity may explain the superior results of the amazonian rural workers when compared to those working in the interior of the São Paulo.

In this State the food ingestion among the rural workers is mainly based on carbohydrates. Certainly the nutritional status plays a role, still to be quantitatively defined, as a determinant of the physical capacity. 


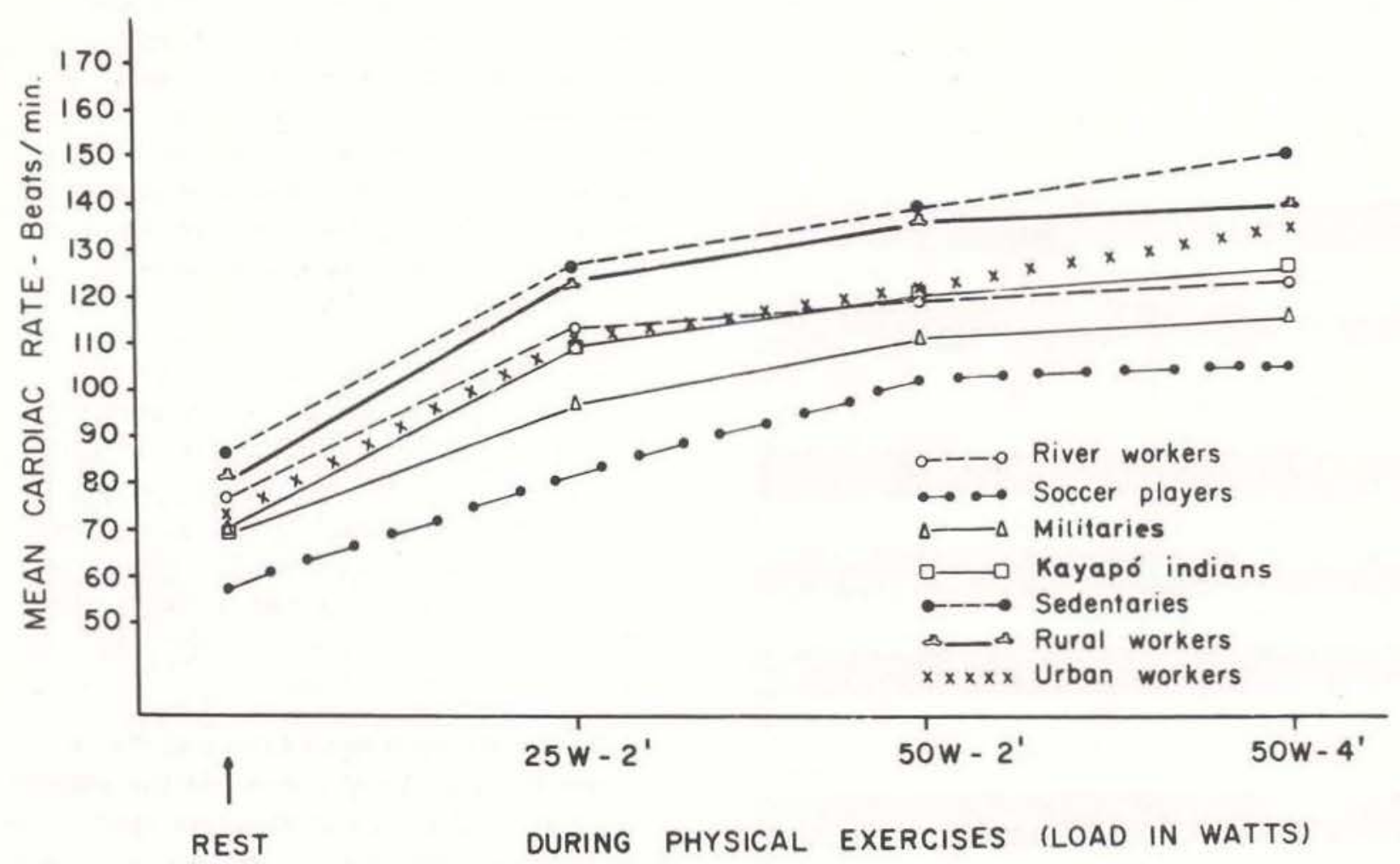

Figure 3 - Evolution of the mean cardiac rate of the seven groups, during the first three stages of the test.

TABLE I - Characteristics (age, height and weight) of the seven population used in the study

\begin{tabular}{|c|c|c|c|c|}
\hline Groups & & $\begin{array}{l}\text { Age * } \\
\text { Years }\end{array}$ & $\underset{\text { cm }}{\text { Height }}$ * & $\underset{\text { kg }}{\text { Weight }}$ \\
\hline River workers & (10) & $30.7 \pm 6.17$ & $165.1 \pm 6.05$ & $71.6 \pm 11.97$ \\
\hline Soccer players & ( 5$)$ & $22.4 \pm 1.52$ & $169.0 \pm 2.92$ & $64.5 \pm 4.44$ \\
\hline Indians (Kayapós) & (10) & $38.7 \pm 14.9$ & $166.6 \pm 2.91$ & $66.3 \pm 5.6$ \\
\hline Militaries & (10) & $19.3 \pm 0.82$ & $165.5 \pm 4.81$ & $71.6 \pm 11.97$ \\
\hline Sedentaries & ( 5$)$ & $37.2 \pm 10.66$ & $164.6 \pm 6.35$ & $64.8 \pm 5.31$ \\
\hline Urban workers & ( 5$)$ & $29.8 \pm 11.37$ & $158.8 \pm 4.76$ & $59.9 \pm 4.13$ \\
\hline Rural workers & (10) & $28.6 \pm 4.25$ & $159.3 \pm 7.38$ & $56.7 \pm 6.6$ \\
\hline
\end{tabular}

(*) Mean and standard deviation.

(*) Figures in brocket indicate number of subjects. 
TABLE II - Average physical activities per day of the persons tested

\begin{tabular}{lcc}
\hline Groups & Hours of work & $\begin{array}{c}\text { Hours } \\
\text { of rest }\end{array}$ \\
\hline River Workers & 8 & 8 \\
Soccer Players & $6+$ Special training & 8 \\
Kayapó Indians & $10(?)$ & $8(?)$ \\
Militaries & 8 & 8 \\
Sedentaries & $8-10$ & $6-8$ \\
Urban Workers & 8 & 8 \\
Rural Workers & 8 & 10 \\
\hline
\end{tabular}

One of the most important conclusion of the study was the demonstration that the physical performance of the amazonians is about the same as the inhabitants of the interior of the State of São Paulo. As a fundamental conclusion, we should state that to live in the tropical region of the Amazon, where temperature and humidity are very high, apparently does not change the physical capacity of man. The only suggested difference was favorable to amazonians (rural workers), and as discussed above, it may be related to a more balanced diet.

TABLE III - Mean heart rate before the physical exercise and at the end of the first three stages of the physical performance test done by ergometric bycicle

\begin{tabular}{|c|c|c|c|c|c|c|}
\hline & & & CHR & $\begin{array}{c}1 \text { st stage } \\
25 w-2^{\prime}\end{array}$ & $\begin{array}{c}2^{\text {nd }} \text { stage } \\
50 \mathrm{w}-2^{\prime}\end{array}$ & $\begin{array}{c}50 \mathrm{w}-4 \text { ' } \\
3^{\text {rd }} \text { stage }\end{array}$ \\
\hline River workers & $(10)$ & 78 & \pm 6.2 & $114 \pm 8.8$ & $120 \pm 9.4$ & $124 \pm 10.6$ \\
\hline Soccer players & ( 5$)$ & 59 & \pm 4.3 & $82 \pm 10.2$ & $103 \pm 8.7$ & $106 \pm 9.4$ \\
\hline Militaries & $(10)$ & 71 & \pm 10.2 & $98 \pm 13.4$ & $107 \pm 15.1$ & $117 \pm 16.0$ \\
\hline Kayapó indians & $(10)$ & 70 & \pm 12.4 & $101 \pm 15.1$ & $116 \pm 14.0$ & $122 \pm 17.0$ \\
\hline Sedentaries & ( 5$)$ & 88 & \pm 5.8 & $121 \pm 11.6$ & $135 \pm 13.1$ & $147 \pm 14.0$ \\
\hline Urban workers & ( 5$)$ & 74 & \pm 8.1 & $103 \pm 9.7$ & $118 \pm 12.0$ & $129 \pm 10.5$ \\
\hline Rural workers & $(10)$ & 83 & \pm 12.6 & $116 \pm 18.6$ & $124 \pm 17.2$ & $134 \pm 18.4$ \\
\hline
\end{tabular}

$\mathrm{CHR}=$ Control Heart Rote

$25 w-2=2$ minute of exercise -25 watts of work

$50 w-2=2$ minute of exercise -50 wotts of work

$50 \mathrm{w}-4=4$ minute of exercise -50 watts of work

TBALE IV - Rest arterial blool pressure (RABP) anda at the end (EABP) of the ergometric test in the seven groups studied

\begin{tabular}{llll}
\hline \multicolumn{1}{c}{ Groups } & & \multicolumn{1}{c}{$\begin{array}{c}\text { RABP } \\
(\mathrm{mmHg})\end{array}$} & $\begin{array}{c}\text { EABP } \\
\text { (mmHg) }\end{array}$ \\
\hline River workers & $(10)$ & $138 \times 82 \pm 14.7 \times 9.7$ & $164 \times 58 \pm 15.2 \times 8.1$ \\
Soccer players & $(5)$ & $116 \times 70 \pm 10.9 \times 11.2$ & $166 \times 47 \pm 14.2 \times 6.7$ \\
Kayapó indians & $(10)$ & $121 \times 77 \pm 15.3 \times 10.2$ & $145 \times 51 \pm 16.7 \times 4.9$ \\
Militaries & $(10)$ & $116 \times 72 \pm 19 \times 8.3$ & $163 \times 58 \pm 13.4 \times 6.3$ \\
Sedentaries & $(5)$ & $132 \times 84 \pm 13.7 \times 9.5$ & $162 \times 65 \pm 14.7 \times 6.9$ \\
Srban workers & $(5)$ & $128 \times 78 \pm 12.7 \times 8.9$ & $168 \times 58 \pm 13.1 \times 9.7$ \\
Rural workers & $(10)$ & $124 \times 72 \pm 14.4 \times 9.2$ & $150 \times 52 \pm 12.8 \times 7.3$ \\
& & & \\
\hline
\end{tabular}




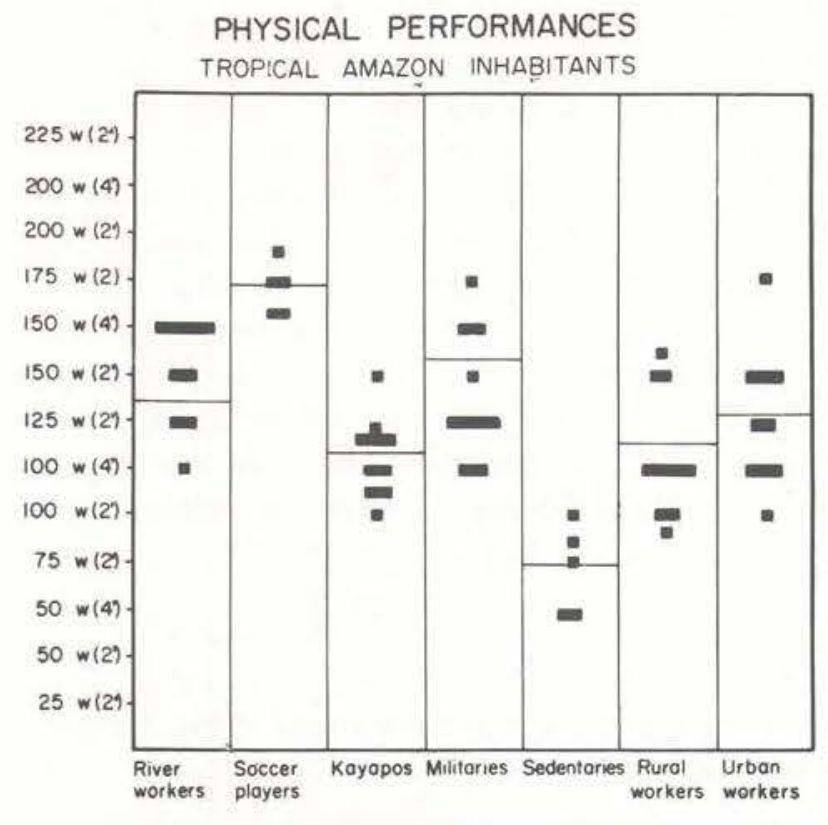

Figure 4 - Graphic demonstration of the levels of physical performance obtained by each person. The horizontal lines mean the average per groups.

A continuation of the investigation is needed. Other amazonians living in the interior and away from the sea should be studied. Other more involved experiments with indians should be sought rapidly, before the influence of civilization increases among them. In the near future, a more physiological technique has to be used in order to obtain new results to compare with those shown in the present paper.

\section{ACKNOLEDGEMENTS}

The auhtors are grateful to Professor Doctor Warwick Estevam Kerr, Director of the Instituto Nacional de Pesquisas da Amazônia, Doctor Luiz Miguel Scaff, Director of the Museu Paraense Emílio Goeldi and Professor Nagib Matne, Director of Escola de Educação Física do Pará.

\section{Resumo}

Um estudo da capacidade física de sete diferentes grupos profissionajs residindo na Amazônia brasileira foi realizado. Determinaram-se suas capacidades utilizando-se a bicicleta ergométrica como método. Os grupos profissionais foram os seguintes: militares, trabalhadores rurais, trabalhadores do porto fluvial de Belém, índios Kayapós não civilizados -10 pessoas de cada. Completaram a série: jogadores profissionais de futebol, sedentários e trabalhadores urbanos -5 pessoas de cada. Os melhores resultados foram obtidos nos futebolistas e militares. Constituindo um segundo agrupamento, situaram-se os demais, com exceção dos sedentários que se revelaram com a pior condição física, bem abaixo dos restantes. E importante ressaltar que os amazonidas de uma forma genérica, embora vivendo em ambientes de altas temperaturas e umidades, demonstraram condiçóes físicas comparáveis com habitantes do interior do Estado de São Paulo (cidade de Ribeirão Preto). Os rurícolas, superaram em aptidão física o grupo estudado em São Paulo. Isto talvez se deva às melhores condiçōes de nutrição dos rurícolas da Amazônia (alta ingestão de proteínas e vitaminas). Os índios Kayapós, cujas capacidades físicas foram talvez determinadas pela primeira vez, demonstraram condicionamentos físicos comparáveis com a. média da população estudada.

\section{LTTERATURE CITED}

ASTRAND, P.O.

1952 - Experimental studies of Physical working capacity in Relation to sex and age. Copenhagen, Einar Munkagaard Forlag.

Balke, B.; Grillo, G.P.; Konecci, E.B. \& Luft, U. C. 1954 - Work capacity after blood donation. J. Appl. Physiol., 7: 231.

BALKe, B. \& WARE, R.W.

1959 - An experimental study of physical fitness of air force personnal. Med. J., $10: 675-688$.'

Fundamentals of Exercise Testing. Who Publication. 1971 - Geneva.

Gardner, G.W.; Edgerton, V.R.; Senewivatne, B.; BARNARD, R.J. \& YOSHINOBU, OHIRA

1977 - Physical work capacity and metabolic stree in subjects with iron deficiency anemia. Am, J. Clin. Nutr., $30: 910-917$.

VICHI, F.L.; PEREIRA, S.R.; MORI, L.E.; RUFINO C.B.R.; Mandeville, J.A.C.; Del Corso, O.; Mellis, B.S. \& TAliberti, A.

1976 - Fatores de risco coronariano em rurfcolas. I. - Capacidade física de trabalhadores rurais e de outros grupos profissionais brasileiros, estudada pelo ciclo-ergometria. Arq. bras. Cardiol., $29: 185-188$.

(Aceito para publicação em 21-06-78) 